\title{
Prostate Cancer cT3 TNM Finding v8
}

National Cancer Institute

\section{Source}

National Cancer Institute. Prostate Cancer CT3 TNM Finding v8. NCI Thesaurus. Code C140139.

Prostate cancer with extraprostatic tumor that is not fixed or does not invade adjacent structures. (from AJCC 8th Ed.) 